\title{
Jet A-1 Bacterial Contamination: a Case Study of Cultivable Bacteria Diversity, Alkane Degradation and Biofilm Formation
}

\author{
Iulia Chiciudean, Ioana Mereuţă, Robertina Ionescu, Tatiana Vassu, \\ Ana-Maria Tănase*, Ileana Stoica \\ Center for Research, Consulting and Training in Microbiology, Genetics and Biotechnology (MICROGEN), \\ Faculty of Biology, University of Bucharest, Bucharest, Romania
}

Received: 25 August 2018

Accepted: 21 October 2018

\begin{abstract}
Bacterial contamination during fuel storage can lead to fuel biodegradation (biodeterioration) or infrastructure problems (i.e., microbiologically influenced corrosion (MIC), biofouling, etc.). Jet A-1 storage tank samples were screened, and 23 morphologically distinct bacterial strains were isolated. 6 isolates revealed biofilm initiation capacity. For 12 isolates the alkane monooxygenase gene (alkB) was successfully detected. The 12 alkB-possessing isolates were 16S rDNA sequences identified as belonging to Bradyrhizobium, Sphingomonas, Bacillus, Pseudomonas, Methylobacterium and Lelliottia genera. In addition to possessing enzymatic equipment $(\mathrm{AlkB})$ required for alkane oxidation, 10 out of 12 isolates were able to use Jet A- 1 and $n$-tetradecane as their sole carbon source and energy. Biofilm initiation capacity and the ability to grow on different hydrocarbons highlights once again that fuel bacterial contamination can lead to serious fuel and storage system alterations. In contrast, their adaptation to high concentrations of hydrocarbons highlights the potential use of our isolates for bioremediation processes.
\end{abstract}

Keywords: Jet A-1, biofilm, alkane deterioration/degradation, alkB genes

\section{Introduction}

Microbial contamination during fuel storage is a chronic problem, especially for Jet A-1 kerosene or diesel fuels. Besides fuel deterioration, microorganism proliferation during storage can lead to system problems such as microbiologically influenced corrosion (MIC) and biofouling. Microbial biofilm formation

*e-mail: ana-maria.tanase@bio.unibuc.ro is the main cause and the first step in biofouling. Through distribution facilities, from storage tanks, microorganisms are transported with fuel to aircraft and sometimes can block the aircraft tank-to-engine filters and have fatal consequences for flight operation. MIC is also associated with biofilm development due to anaerobic bacteria. Fuel deterioration is associated with aerobic biodegradation of fuel hydrocarbons and it is a cause of fuel failing specification tests that result in loss of commercial value [1].

As previously emphasized, fuel biodegradation has negative (biodeterioration) or positive (bioremediation) connotations only from a commercial point of view [1]. 
Although microbial growth in Jet A-1 storage tanks can cause a variety of serious problems, it is reasonable to suppose that microbes that are able to proliferate at such high hydrocarbon concentrations might be powerful candidates for bioremediation (bioaugmentation) processes [2, 3].

The first and most important step in the aerobic bacterial degradation of alkanes (the major fractions of Jet A-1 hydrocarbons) is catalyzed by oxygenases. These enzymes play an important role in fuel biodeterioration or bioremediation. Up until the present, the best characterized alkane oxygenase is rubredoxin-dependent alkane monooxygenase $\mathrm{AlkB}$, encoded by the alkB gene [4]. Specific detection of alkB biomarker genes by PCR using strain-specific oligonucleotide primers or degenerate oligonucleotides $[4,5]$ without any obvious strain-specific discrimination, is frequently used to determine the abundance and diversity of alkanedegrading bacteria in various ecosystems [6].

Besides fuel deterioration, some of the major problems associated with microbial growth in fuel storage systems are biofouling, sludge formation within pipes and valves, and filter blockage. Under these circumstances, it becomes very important to test Jet A-1 tank bacterial isolates for biofilm formation capacities [7, 8].

Thus, considering all the above-mentioned aspects regarding microbial contamination of Jet A-1, it becomes necessary to evaluate the extent of microbial implications on the quality of fuel and biofouling under storage conditions and to extrapolate those findings to a useful extent, such as bioremediation of fuel spills.

In this context, the current study focusses on (i) estimating the implications of Jet A-1 storage tank bacterial contaminants in system-related problems (biofouling) and fuel deterioration, (ii) revealing the taxonomic identity of potential hydrocarbon (alkanes)degrading bacteria strains, and (iii) investigating their alkanes utilization ability for an eventual use as candidates for bioremediation or as experimental strains used to unfold important fuel degradation aspects.

\section{Materials and Methods}

\section{Isolation and Characterization of Cultivable Microorganisms}

Aqueous phase samples from the bottom of 7 Jet A-1 storage tanks were collected, serially diluted and spread onto R2 agar (R2A) and Luria-Bertani agar (LBA). After 2 days of incubation $\left(28^{\circ} \mathrm{C}\right)$, morphologically distinct colonies were picked, checked for purity and stored at $-80^{\circ} \mathrm{C}$ in $25 \%$ glycerol.

Phenotypic characterization of bacterial isolates was based on colony morphology, Gram stain reaction, oxidase and catalase tests and Biolog metabolic arrays (Biolog, Hayward, CA, USA). For Biolog biochemical tests, bacterial strains were grown according to the Biolog GN/GP microplates manufacturer recommendations. Strains were incubated at $28^{\circ} \mathrm{C}$ until plate readings by a MicroLog MicroStation.

\section{Biofilm Formation Asay}

Biofilm formation assays were conducted according to a modified version of the O'Toole and Kolter method [9]. Microtiter plates containing $200 \mu \mathrm{l}$ LB broth/well were inoculated with $10 \mu \mathrm{l}$ cell suspension $\left(\mathrm{OD}_{600 \mathrm{~nm}}=1\right)$ and incubated at $28^{\circ} \mathrm{C}$ for $24 \mathrm{~h}$. Formed biofilms were stained with $0.1 \% \mathrm{w} / \mathrm{v}$ crystal violet solution for $15 \mathrm{~min}$ and then washed with distilled water. Biofilm-attached dye was extracted in $200 \mu \mathrm{l} /$ well $95 \%$ ethanol and quantified by $\mathrm{OD}_{590 \mathrm{~nm}}$ measurements (Biolog MicroLog MicroStation). All experiments were performed in triplicate with appropriate controls.

\section{DNA Isolation}

Genomic DNA extraction was performed using a Purelink Genomic DNA kit (Invitrogen) according to the manufacturer's recommendations. DNA purity and concentration were determined by spectrophotometry (GE Healthcare NanoVue Plus ${ }^{\mathrm{TM}}$ ) and $0.8 \%$ (w/v) agarose gel electrophoresis.

\section{alkB Gene Screening}

Detection of the alkane hydroxylase gene was performed by PCR amplification using two sets of oligonucleotide primers: alkB-1f/alkB-1r [4] and ALK-3F/ALK-3R [5]. Those primers were designed based on alkB sequences, including the alkB gene sequence of Pseudomonas (P.) protegens CHA0 (AJ009579). Type strain $P$. protegens CHA0 [10], used as alkB-PCR positive control, was obtained from Leibniz Institute DSMZ-German Collection of Microorganisms and Cell Cultures. PCR reactions were carried out in a final volume of $25 \mu \mathrm{l}$, containing: $100 \mathrm{ng}$ genomic DNA, $12.5 \mu \mathrm{l}$ Dream Taq Green $(2 \mathrm{X})$ (Thermo Scientific), $10 \mu \mathrm{M}$ for each primer and water up to the final volume. For alkB-1f/alkB-1r primers, the temperature cycling conditions were: $95^{\circ} \mathrm{C}$ for $10 \mathrm{~min}$, 15 cycles of $94^{\circ} \mathrm{C}$ for $30 \mathrm{~s}, 51^{\circ} \mathrm{C}$ for $30 \mathrm{~s}, 72^{\circ} \mathrm{C}$ for $60 \mathrm{~s}$, followed by 20 cycles of $94^{\circ} \mathrm{C}$ for $30 \mathrm{~s}, 55^{\circ} \mathrm{C}$ for $30 \mathrm{~s}$, $72^{\circ} \mathrm{C}$ for $60 \mathrm{~s}$, and a final elongation at $72^{\circ} \mathrm{C}$ for $5 \mathrm{~min}$. For primer pair $\mathrm{ALK}-3 \mathrm{~F} / \mathrm{ALK}-3 \mathrm{R}$ the temperature cycling conditions were: $95^{\circ} \mathrm{C}$ for $5 \mathrm{~min}, 35$ cycles of $94^{\circ} \mathrm{C}$ for $30 \mathrm{~s}, 60^{\circ} \mathrm{C}$ for $30 \mathrm{~s}, 72^{\circ} \mathrm{C}$ for $60 \mathrm{~s}$ and a final elongation at $72^{\circ} \mathrm{C}$ for $5 \mathrm{~min}$. PCR products were checked by $1 \%(\mathrm{w} / \mathrm{v})$ agarose gel electrophoresis.

\section{Microorganism Identification}

16S rRNA gene from all positive alkB strains was amplified by PCR using universal primers $27 \mathrm{~F}$ 
(5'- AGA GTT TGA TCM TGG CTC AG - 3') and 1492R (5'- CGG TTA CCT TGT TAC GAC TT - 3'). PCR reactions were carried out in a final volume of $50 \mu \mathrm{l}$, containing: $100 \mathrm{ng}$ genomic DNA, $25 \mu \mathrm{l}$ Dream Taq Green (2X) (Thermo Scientific), $1 \mu l$ for each primer $(10 \mu \mathrm{M})$ and nuclease-free water up to the final volume. Cycling parameters were $95^{\circ} \mathrm{C}$ for $5 \mathrm{~min}$, followed by 30 cycles of $95^{\circ} \mathrm{C}$ for $1 \mathrm{~min}, 58^{\circ} \mathrm{C}$ for $30 \mathrm{~s}$, and $72^{\circ} \mathrm{C}$ for $2 \mathrm{~min}$, with a final step at $72^{\circ} \mathrm{C}$ for $10 \mathrm{~min}$. Positive amplification products were purified using a Favor Prep PCR Clean-up Mini kit (Favorgene Biotech Corp., Taiwan) and sequenced by GENETIC LAB (Bucharest, Romania) using the primer sets 27F/1492R or $27 \mathrm{~F} / 533 \mathrm{~F}$ (5'-GTG CCA GCA GCC GCG GTA A-3'). Strain identification was based on their rDNA sequences comparison with GenBank using the BLAST algorithm from EzTaxon.

\section{Microbial Growth on Hydrocarbons}

Bacterial growth on aliphatic hydrocarbons was evaluated using $30 \mathrm{ml}$ screw cap sealed flasks containing $10 \mathrm{ml}$ minimal salts medium (MSM) (per liter: $\mathrm{Na}_{2} \mathrm{HPO}_{4} \cdot 12 \mathrm{H}_{2} \mathrm{O} 1 \mathrm{~g}, \mathrm{KH}_{2} \mathrm{PO}_{4} 0.5 \mathrm{~g},\left(\mathrm{NH}_{4}\right)_{2} \mathrm{SO}_{4}$ $\left.1 \mathrm{~g}, \mathrm{MgSO}_{4} \cdot 7 \mathrm{H}_{2} \mathrm{O} 0.2 \mathrm{~g}, \mathrm{NaCl} 1 \mathrm{~g}, \mathrm{pH} 7.0\right)$ supplemented with hydrocarbons $1 \%(\mathrm{v} / \mathrm{v})$ ( $n$-tetradecane (C14) or Jet A-1) as the sole carbon source, and inoculated with bacterial culture (to a final $\mathrm{OD}_{600 \mathrm{~nm}}=0.1$ ). Flasks were incubated at $28^{\circ} \mathrm{C}, 150 \mathrm{rpm}$ for 30 days. Microbial multiplication was determined at the end of the incubation period by measurement of $\mathrm{OD}_{600 \mathrm{~nm}}$. All experiments were performed in triplicate with appropriate controls.

\section{Results and Discussion}

\section{Microbiological Phenotypic Characterization and Biofilm Formation}

Morphologically distinct bacterial colonies, designated D1-D23, were directly isolated from the fuel tank water layer on R2A and LBA plates. As expected for oligotrophic bacteria, the majority of isolates exhibited a better growth on R2A than on rich LBA medium. Basic microbiological characterization and Biolog biochemical tests were performed for all the isolates (Tables 1, 2).

In biofouling and system-related problems involving microbial colonization and deposition of biofoulants, microorganisms need to (i) have biofilm formation abilities and (ii) proliferate in fuel storage conditions using Jet A-1 hydrocarbons.

Biofilm formation capacity $\left(\mathrm{OD}_{590 \mathrm{~nm}}\right.$ values for adherent cells) was highlighted for 6 out of 23 bacterial isolates: an $\mathrm{OD}>1.4$ was obtained for strains D4, D18, D19; for D2, D15, D16 strains was registered a moderate biofilm formation $(\mathrm{OD}<0.7)$ (Fig. 1). Three of those isolates (D2, D15, D19) were 16S rRNA identified as closely related to Bacillus simplex, Pseudomonas synxantha and Sphingomonas zeae commonly found in biofilms $[11,12]$. Due to the short period of incubation used for this assay $(24 \mathrm{~h})$, those 6 biofilm-forming isolates could be considered the primary colonizers, responsible for initial adhesion step of biofilm formation and could be involved in biofouling, sludge formation, and pipes/valves/filters blockage events.

Table 1. Cell morphology, reaction to Gram staining, oxidase and catalase production of direct isolates.

\begin{tabular}{|c|c|c|c|c|c|c|c|}
\hline $\begin{array}{c}\text { Bacterial } \\
\text { isolate }\end{array}$ & $\begin{array}{c}\text { Cell } \\
\text { morphology }\end{array}$ & $\begin{array}{c}\text { Gram } \\
\text { staining }\end{array}$ & $\begin{array}{c}\text { Oxidase } \\
\text { and catalase tests }\end{array}$ & $\begin{array}{c}\text { Bacterial } \\
\text { isolates }\end{array}$ & $\begin{array}{c}\text { Cell } \\
\text { morphology }\end{array}$ & $\begin{array}{c}\text { Gram } \\
\text { staining }\end{array}$ & $\begin{array}{c}\text { Oxidase } \\
\text { and catalase tests }\end{array}$ \\
\hline D1 & bacilli & $(-)$ & Oxi(+) & D12 & bacilli & $(-)$ & Oxi(-) \\
\hline D2 & bacilli & $(+)$ & Cat(+) & D13 & bacilli & $(-)$ & Oxi(-) \\
\hline D3 & bacilli & $(-)$ & Oxi(-) & D14 & bacilli & $(-)$ & Oxi(+) \\
\hline D4 & cocci & $(+)$ & Cat(+) & D15 & bacilli & $(-)$ & Oxi(+) \\
\hline D5 & bacilli & $(+)$ & Cat(-) & D16 & cocci & $(+)$ & Cat(-) \\
\hline D6 & cocci & $(+)$ & Cat(+) & D17 & bacilli & $(+)$ & Cat(+) \\
\hline D7 & bacilli & $(-)$ & Oxi(-) & D18 & cocci & $(+)$ & Cat(+) \\
\hline D8 & cocci & $(+)$ & Cat(+) & D19 & bacilli & $(-)$ & Oxi(+) \\
\hline D9 & bacilli & $(+)$ & Cat(-) & D20 & bacilli & $(-)$ & Oxi(-) \\
\hline D10 & cocci & $(+)$ & Cat(+) & D21 & bacilli & $(+)$ & Cat(+) \\
\hline D11 & bacilli & $(+)$ & Cat(+) & D22 & bacilli & $(-)$ & Oxi(+) \\
\hline
\end{tabular}


Table 2. BIOLOG taxonomic identification of bacterial isolates.

\begin{tabular}{|c|c|c|c|c|c|}
\hline $\begin{array}{c}\text { Bacterial } \\
\text { isolates }\end{array}$ & Biolog identification & $\begin{array}{c}\text { Similarity } \\
\text { index* }\end{array}$ & $\begin{array}{c}\text { Bacterial } \\
\text { isolates }\end{array}$ & Biolog identification & Similarityindex* \\
\hline D1 & Acidovorax sp. & 0.448 & D13 & Kluyvera cryocrescens & 0.518 \\
\hline D2 & Bacillus anthracis & 0.492 & D14 & Burkholderia glumae & 0.769 \\
\hline D3 & Ralstonia sp. & 0.411 & D15 & Pseudomonas fluorescens & 0.708 \\
\hline D4 & Kocuria kristinae & 0.786 & D16 & Staphylococcus sp. & 0.465 \\
\hline D5 & Curtobacterium pusillum & 0.626 & D17 & Bacillus sp. & 0.471 \\
\hline D6 & Micrococcus luteus & 0.721 & D18 & Micrococcus luteus & 0.528 \\
\hline D7 & Xanthomonas campestris & 0.741 & D19 & Sphingomonas terrae & 0.816 \\
\hline D8 & Staphylococcus xylosus & 0.547 & D20 & Acinetobacter sp. & 0.327 \\
\hline D9 & Arcanobacterium bernardiae & 0.610 & D21 & Bacillus anthracis & 0.651 \\
\hline D10 & Staphylococcus xylosus & 0.531 & D22 & Pseudomonas tolaasii & 0.642 \\
\hline D11 & Bacillus anthracis & 0.500 & D23 & Pseudomonas synxantha & 0.734 \\
\hline D12 & Kluyvera cryocrescens & 0.620 & & & \\
\hline
\end{tabular}

*First choice from the similarity list of species that most closely matches the unidentified strain.

\section{Molecular Screening of Alkane Hydroxylase Genes}

In order to estimate the ability of the 23 bacterial isolates to be involved in fuel hydrocarbon deterioration/ degradation, alkane hydroxylase alkB genes presence was investigated by PCR-amplification with two sets of primers $[4,5]$. The medium-chain-length alkanes (C10 to C16) hydroxylation enzyme AlkB (EC 1.14.15.3) gene, is the most common gene that has been used for investigating the composition of alkane-degrading communities and for abundance estimation of oildegrading bacteria in various environments [10].

In this study, the appropriate size alkB PCR fragments were obtained for 12 out of 23 bacterial isolates, all showing the expected $a l k B$ gene fragments of 330 bp using ALK-3F/ALK-3R-specific primers (Fig. 2). For bacterial isolates D14, D19, D22, D23, where non-specific amplifications were observed, alkB gene fragments of 550bp were successfully amplified with the highly degenerated primers alkB-1f/alkB-1r for confirmation (Fig. 2). Non-alkB possessing strains can either use Jet A-1 aromatic fraction, use different enzymatic systems for alkane degradation or cannot metabolize Jet A-1 hydrocarbons [13].

The 12 alkB-possessing bacterial strains were $16 \mathrm{~S}$ rRNA identified as belonging to 6 genera (Table 3), with the prevalence of Bacillus and Pseudomonas species. The dominant phyla for the 12 identified, alkB-possessing isolates was Proteobacteria (Table 4).

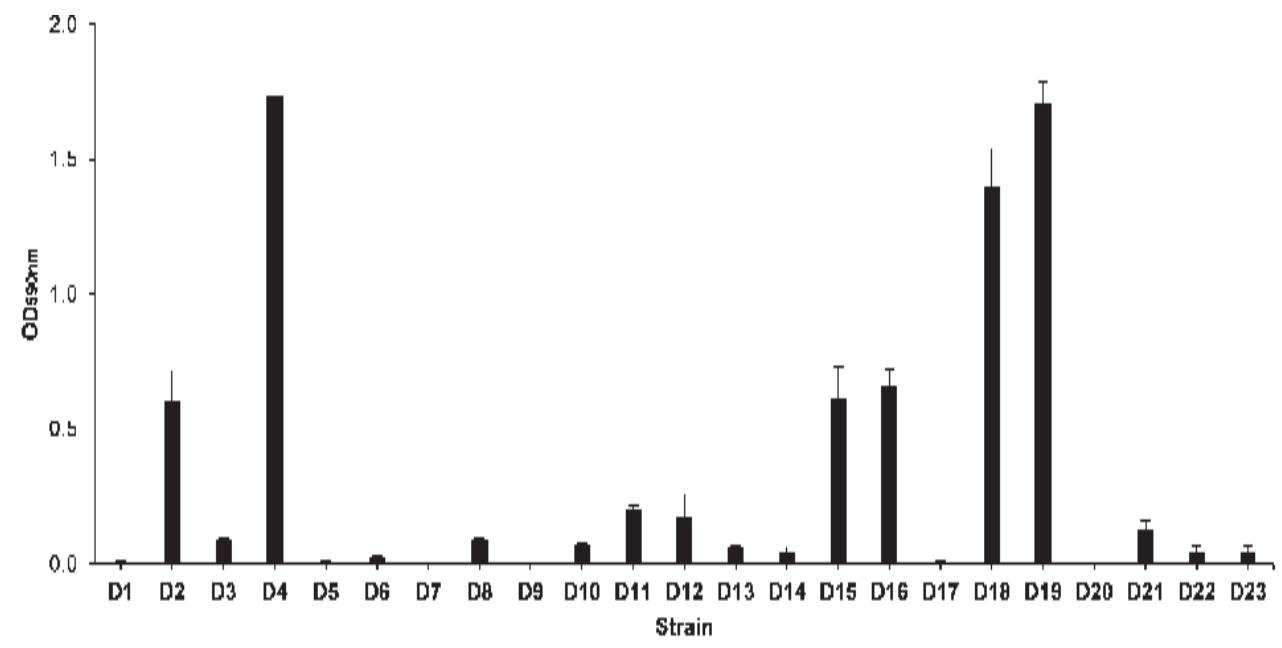

Fig. 1. Biofilm formation capacity of all Jet A-1 storage tanks isolates. The height of the bars represents adherent cells $\mathrm{OD}_{590 \mathrm{~nm}}$ after 24 hours of incubation. Error bars display standard deviation based on four replicate wells. 


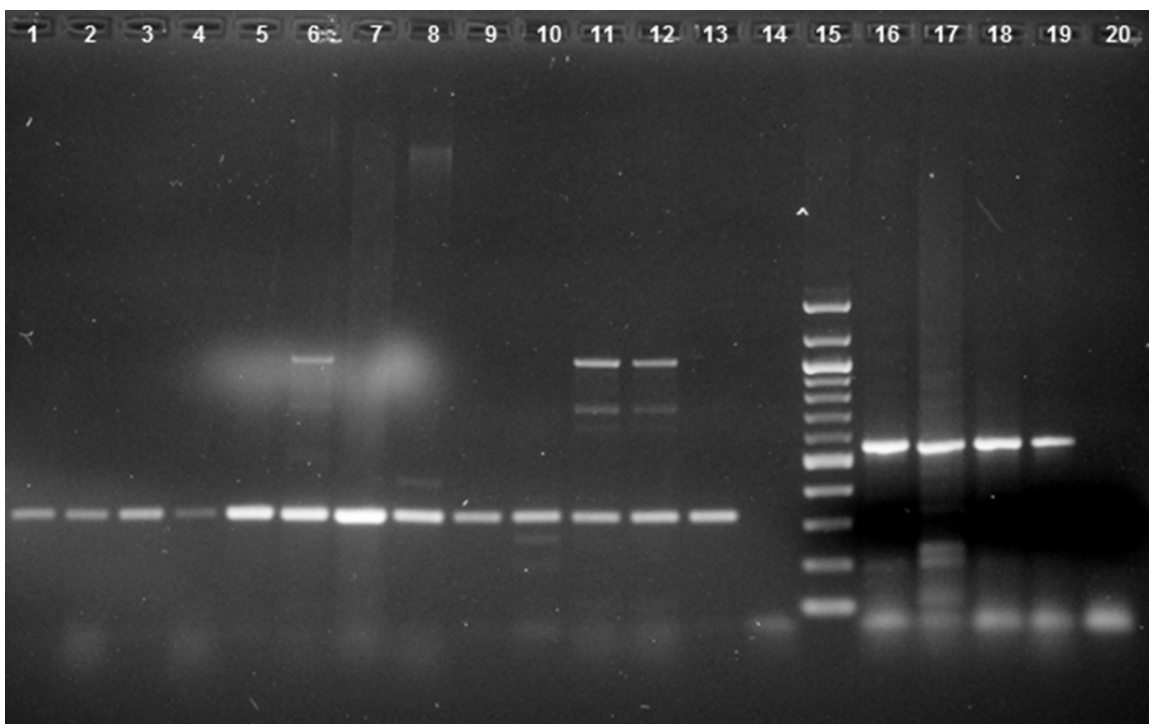

Fig. 2. Detection of alkB gene for direct isolates with ALK-B3F/ALK-B3R (lanes 1-14) and alkB-1f/alkB-1r (lanes 16-20). Lanes 1-14: D1, D2, D11, D12, D13, D14, D15, D19, D20, D21, D22, D23, P. protegens CHA0, no DNA control; lane 15: 100 bp DNA Ladder (New England Biolabs); lanes 16-20: D14, D19, D22, D23, no DNA control.

This it is in accordance with the previously reported dominance of Proteobacteria (Gammaproteobacteria) among fuel-isolated bacterial taxa by both cultivationdependent and independent methods [14, 15].

Besides such frequent fuel-contaminating genera as Bacillus, Pseudomonas and Sphingomonas [14, 16], two bacterial isolates (D12, D13) were closely related to Lelliottia amnigena (former Enterobacter amnigenus). To the best of our knowledge, this is the first time the Lelliottia genus is mentioned among fuel-isolated bacteria or for possessing alkane monooxygenases codind genes. Isolates closely related with Bradyrhizobium denitrificans (D1) and Methylobacterium platani (D20) were previously mentioned as isolated from different fuel samples [14, 16-18] and associated with biofilms and MIC [19]. In the current study we found no correlation between biofilm formation and $B$. denitrificans D1 and M. platani D20 isolates (Fig. 1). Due to the ironrespiring (Bradyrhizobium sp.) and methane-oxidizing (Methylobacterium sp.) abilities, we consider that those genera could be biofilm inhabitants in the latest stages of biofilm development. The Gammaproteobacteria group found in our jet A-1 samples was mainly comprised of members of the Pseudomonas genus. The most abundant Pseudomonas species showed more than 99.7\% 16S rRNA gene similarity to the $P$. extremaustralis/veronii lineage, species mentioned in relation with aromatic compounds degradation [20].

Table 3. 16S rDNA sequence taxonomic affiliation of bacterial isolates.

\begin{tabular}{|c|c|c|c|}
\hline Strains & Molecular identification* & Class & Phylum \\
\hline D1 & Bradyrhizobium denitrificans & $\alpha$-proteobacteria & Proteobacteria \\
\hline D2 & Bacillus simplex, B. frigoritolerans & Bacilli & Firmicutes \\
\hline D11 & Bacillus cereus, B. anthracis & Bacilli & Firmicutes \\
\hline D12 & Lelliottia amnigena & $\gamma$-proteobacteria & Proteobacteria \\
\hline D13 & Lelliottia amnigena & $\gamma$-proteobacteria & Proteobacteria \\
\hline D14 & Pseudomonas extremaustralis & $\gamma$-proteobacteria & Proteobacteria \\
\hline D15 & Pseudomonas synxantha & $\gamma$-aproteobacteria & Proteobacteria \\
\hline D19 & Sphingomonas zeae, S.aeria & $\alpha$-proteobacteria & Proteobacteria \\
\hline D20 & Methylobacterium aquaticum, M. variabile, $M$. tarhaniae & $\alpha$-proteobacteria & Proteobacteria \\
\hline D21 & Bacillus cereus, B. anthracis & Bacilli & Firmicutes \\
\hline D22 & Pseudomonas extremaustralis & $\gamma$-proteobacteria & Proteobacteria \\
\hline D23 & Pseudomonas extremaustralis & $\gamma$-proteobacteria & Proteobacteria \\
\hline
\end{tabular}


Table 4. 16S rDNA sequences taxonomic identification of isolates.

\begin{tabular}{|c|c|c|c|}
\hline Strains & Accession no. & Molecular identification* & Similarity (\%) \\
\hline D1 & KY973665 & Bradyrhizobium denitrificans & 99.82 \\
\hline D2 & KY973666 & Bacillus simplex, B. frigoritolerans & 99.82 \\
\hline D11 & KY973667 & Bacillus cereus, B. anthracis & 99.91 \\
\hline D12 & KY973668 & Lelliottia amnigena & 98.88 \\
\hline D13 & KY973669 & Lelliottia amnigena & 99.74 \\
\hline D14 & KY973670 & Pseudomonas extremaustralis & 99.83 \\
\hline D15 & KY973671 & Pseudomonas synxantha & 98.88 \\
\hline D19 & KY973672 & Sphingomonas zeae, S. aeria & 98.05 \\
\hline D20 & MG000973 & Methylobacterium platani, M. aquaticum, . variabile & 99.91 \\
\hline D21 & KY973673 & Bacillus cereus, B. anthracis & 99.73 \\
\hline D22 & KY973674 & Pseudomonas extremaustralis & 99.91 \\
\hline D23 & KY973675 & Pseudomonas extremaustralis & \\
\hline
\end{tabular}

* Identification based on comparison of their rDNA 16S sequences with GenBank by BLAST algorithm from EzTaxon. The closest relative type strain is detailed. Only hits with the same similarity percentage are included.

Bacillus species are frequently isolated from fuel storage tanks, one of the reasons being the high resistance to fuel additives due to their endosporeforming features. Species closely related to B. cereus and $B$. anthracis were previously described as contaminants for aviation fuels (i.e., JP-8) [15].

Even though the 16S rRNA gene is the basis for phylogenetic analysis and taxonomic identification of bacteria and new, improved techniques are continuously implemented for assessing diversity and metabolic profiles of microbes, methods like Biolog biochemical tests identification system it is still considered to offer relevant taxonomic information [21]. This identification method was employed in the past for environmental isolate taxonomic identification and found to be $68.3 \%$ accurate compared to the $90.6 \%$ identification accuracy given by $16 \mathrm{~S}$ gene sequencing $[22,23]$. Based on the degree of correlation between 16S taxonomic affiliations and Biolog MicroLog system identification of our 12 identified bacterial isolates (Table 2 and 3), we concluded that the Biolog system has a limited discriminatory power but was accurate to the genus level for 7 out of 12 bacterial isolates.

16S rRNA genes sequenced of the 12 alkB-possessing isolates in this study have the NCBI accession numbers KY973665-KY973675 and MG000973, and the Blast identification results are summarized in Table 4.

\section{Hydrocarbon-Degrading Potential}

Further, all the 12 alkB gene-possessing isolates were tested for their ability to grow on Jet A-1 and

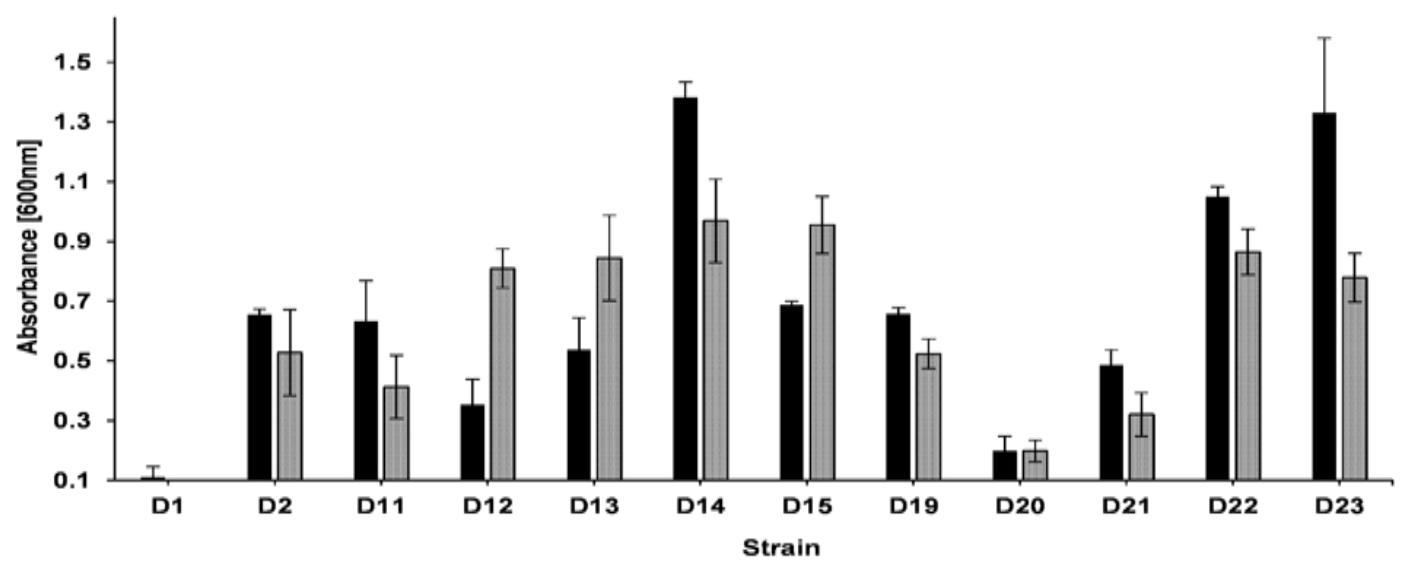

Fig. 3. Growth of alkB-possessing bacterial strain $\left(\mathrm{OD}_{600 \mathrm{~nm}}\right)$ on minimal salts medium (MSM) supplemented with $1 \%$ Jet A-1 (black bars) or $n$-tetradecane (C14) (grey bars) as the sole carbon source after 30 days of incubation at $28^{\circ} \mathrm{C}$. Error bars display standard deviation based on three replicates. 
one of the medium chain length Jet A-1 alkanes (C14) used as the sole carbon sources (Fig. 3). Except for Bradyrhizobium and Methylobacterium species (D1, D20), all other bacterial isolates were able to grow on tested hydrocarbons up to a final $\mathrm{OD}_{600} \mathrm{~nm}$ between 0.25 and 1.33 .

As expected for Pseudomonas species, known as important hydrocarbon degraders and often mentioned as being implicated in Jet A-1 biodegradation [3,15], our P. extremaustralis strains (D14, D22, D23) highlighted the best growth values on both tested substrates. Biomass accumulation was higher using Jet A-1 mixture $\left(\mathrm{OD}_{600 \mathrm{~nm}}>1\right)$, probably due to the $P$. extremaustralis strain ability to degrade different kerosene fractions [20, 24]. In contrast, for $P$. synxantha D15 strain bacterial growth was poorly supported by the Jet A-1 and the higher biomass accumulation was obtained using C14 alkanes as the sole carbon source. Interestingly, C14 also supported the growth of Lelliottia amnigena D12 and D13 strains. To the best of our knowledge, species of Lelliottia were never before described as hydrocarbon degraders. Jet A-1 mixture was preferred over C14 also by Bacillus sp. (D2, D11, D21) and Sphingomonas sp. (D19) bacterial isolates, but both tested substrates supported only a moderate grown for those strains. Bradyrhizobium and Methylobacterium species (D1, D20) were the only bacterial isolates that showed weak or no growth on tested hydrocarbons, although they possess the alkB gene encoding for alkane hydroxylase. This is either because their $a l k B$ gene is not a functional gene, or they are very slow growing bacteria since the cells were still viable by the end of the incubation period but exhibited no significant growth.

\section{Conclusions}

Jet A-1 is a middle distillate petroleum product - a mixture of: alkanes, cycloalkanes, aromatics and olefines from approximately C9-C20 lengths [3]. Bacterial contamination of such a complex hydrocarbon mixture is of interest in terms of fuel deterioration and system-related problems, as well as in terms of finding the best candidates for bioremediation processes. In this study the presumed connection between Jet A-1 bacterial contamination during storage, system-related problems, and contaminant bioremediation potential was confirmed by highlighting the bacteria isolates capacity to initiate biofilm, possess the genetic features needed for alkane degradation and by showing their ability to use hydrocarbons as the sole carbon source and energy.

The present study highlighted the capacity of different bacteria strains to colonize fuel storage tanks, be implicated in subsequent system problems associated with biofilm formation, and their involvement in fuel hydrocarbon deterioration/degradation, additionally underlining their potential use as experimental strains in revealing important fuel contamination and deterioration aspects or as candidates in bioremediation processes. The current study also revealed a new hydrocarbondegrader Lelliottia species, represented by strains D12 and D13, which has not been previously mentioned among fuel-contaminating bacteria or for possessing the enzymatic equipment (alkB) required for alkane oxidation.

\section{Conflict of Interest}

The authors declare no conflict of interest.

\section{References}

1. PASSMAN F.J. Microbial contamination and its control in fuels and fuel systems since 1980 - a review. Int. Biodeterior. Biodegrad. 81, 88, 2013.

2. HEYDARNEZHAD F., HOODAJI M., SHAHRIARINOU M., TAHMOURESPOUR A., SHARIATI S. Optimizing Toluene Degradation by Bacterial Strain Isolated from Oil-Polluted Soils. Pol. J. Environ. Stud. 27, 655, 2018.

3. GOUDA M.K., OMAR S.H., CHEKROUD Z.A., NOUR ELDIN H.M. Bioremediation of Jet A-1 I: A case study in liquid media. Chemosphere. 69, 1807, 2007.

4. KLOOS K., MUNCH J.C., SCHLOTER M. A new method for the detection of alkane-monooxygenase homologous genes $($ alkB) in soils based on PCR-hybridization. J. Microbiol. Methods. 66, 486, 2006.

5. KOHNO T., SUGIMOTO Y., SEI K., MORI K. Design of PCR Primers and Gene Probes for General Detection of Alkane-Degrading Bacteria. Microbes Environ. 17, 114, 2002.

6. JURELEVICIUS D., ALVAREZ V.M., PEIXOTO R., ROSADO A.S., SELDIN L. The Use of a Combination of alkB Primers to Better Characterize the Distribution of Alkane-Degrading Bacteria. PLoS ONE. 8, 13, 2013.

7. HUANG T.-P., SOMERS E.B., WONG A.C.L. Differential Biofilm Formation and Motility Associated with Lipopolysaccharide / Exopolysaccharide-Coupled Biosynthetic Genes in Stenotrophomonas maltophilia. J. Bacteriol. 188, 3116, 2006.

8. SHIMADA K., ITOH Y., WASHIO K., MORIKAWA M. Efficacy of forming biofilms by naphthalene degrading Pseudomonas stutzeri T102 toward bioremediation technology and its molecular mechanisms. Chemosphere. 87, 226, 2012.

9. O'TOOLE G.A., KOLTER R. Initiation of biofilm formation in Pseudomonas fluorescens WCS365 proceeds via multiple, convergent signalling pathways: a genetic analysis. Mol. Microbiol. 28, 449, 1998.

10. SMITS T.H.M., BALADA S.B., WITHOLT B., VAN BEILEN J.B. Functional Analysis of Alkane Hydroxylases from Gram-Negative and Gram-Positive Bacteria. J. Bacteriol. 184, 1733, 2002.

11. BERESCHENKO L.A., STAMS A.J.M., EUVERINK G.J.W., VAN LOOSDRECHT, M.C.M. Biofilm Formation on Reverse Osmosis Membranes Is Initiated and Dominated by Sphingomonas spp.. Appl. Environ. Microbiol. 76, 2623, 2010.

12. LEMOS M., BORGES A., TEODÓSIO J., ARAÚJO P., MERGUlHÃO F., MELO L., SIMÕESET M. The effects of ferulic and salicylic acids on Bacillus cereus 
and Pseudomonas fluorescens single- and dual-species biofilms. Int Biodeterior Biodegrad. 86, 42, 2014.

13. VAN BEILEN J.B., LI Z., DUETZ W.A., SMITS T.H.M., WITHOLT B. Diversity of alkane hydroxylase systems in the environment. Oil Gas Sci Technol. 58, 427, 2003.

14. WHITE J., GILBERT J., HILL G., HILL E., HUSE S.M., WEIGHTMAN A.J., MAHENTHIRALINGAM E. Culture-Independent Analysis of Bacterial Fuel Contamination Provides Insight into the Level of Concordance with the Standard Industry Practice of Aerobic Cultivation. Appl Environ Microbiol. 77, 4527, 2011.

15. MARTIN-SANCHEZ P.M., GORBUSHINA A.A., TOEPEL J. Quantification of microbial load in diesel storage tanks using culture- and qPCR-based approaches. Int Biodeterior Biodegrad. 126, 216, 2018.

16. BROWN L.M., MCCOMB J.P., VANGSNESS M.D., BOWEN L.L., MUELLER S.S., BALSTER L.M., BLECKMANN C.A. Community dynamics and phylogenetics of bacteria fouling Jet A-1 and JP-8 aviation fuel. Int Biodeterior Biodegrad. 64, 253, 2010.

17. LEE J.S., RAY R.I., LITTLE B.J. An assessment of alternative diesel fuels: microbiological contamination and corrosion under storage conditions. Biofouling. 26, 623, 2010.

18. BÜCKER F., SANTOS BARBOSA C., DÖRR QUADROS P., KRÜGER BUENO M., FIORI P., TE HUANG C., GUEDES FRAZZON A.P., FLORES FERRÃO M., DE OLIVEIRA CAMARGO F.A., MENEZES BENTO F. Fuel biodegradation and molecular characterization of microbial biofilms in stored diesel/biodiesel blend B10 and the effect of biocide. Int Biodeterior Biodegrad. 95, 346, 2014.
19. BOLTON N., CRITCHLEY M., FABIEN R., CROMAR N., FALLOWFIELD H. Microbially influenced corrosion of galvanized steel pipes in aerobic water systems. J. Appl. Microbiol. 109, 239, 2010.

20. TÁNCSICS A., FARKAS M., SZOBOSZLAY S., SZABÓ I., KUKOLYA J., VAJNA B., KOVÁCS B., BENEDEK T., KRISZT B. One-year monitoring of meta-cleavage dioxygenase gene expression and microbial community dynamics reveals the relevance of subfamily I.2.C extradiol dioxygenases in hypoxic, BTEX-contaminated groundwater. Syst Appl Microbiol 36, 339, 2013.

21. WRAGG P., RANDALL L., WHATMORE A.M. Comparison of Biolog GEN III MicroStation semiautomated bacterial identification system with matrixassisted laser desorption ionization-time of flight mass spectrometry and $16 \mathrm{~S}$ ribosomal RNA gene sequencing for the identification of bacteria of veterinary interest. J. Microbiol. Methods, 105, 16, 2014.

22. MORGAN M.C., BOYETTE M., GOFORTH C., SPERRY K.V., GREENE S.R., Comparison of the Biolog Omni Log Identification System and 16S ribosomal RNA gene sequencing for accuracy in identification of atypical bacteria of clinical origin. J Microbiol Methods. 79, 336, 2009.

23. MILLER J.M., RHODEN D.L. Preliminary evaluation of Biolog, a carbon source utilization method for bacterial identification. J. Clin. Microbiol. 29, 1143, 1991.

24. STRIEBICH RC, SMART CE, GUNASEKERA TS, ET AL, MUELLER, S.S., STROBEL, E.M, MCNICHOLS, M.W., RUIZ, O.N. Characterization of the F-76 diesel and Jet-A aviation fuel hydrocarbon degradation profiles of Pseudomonas aeruginosa and Marinobacter hydrocarbonoclasticus. Int Biodeterior Biodegrad. 93, 33, 2014. 